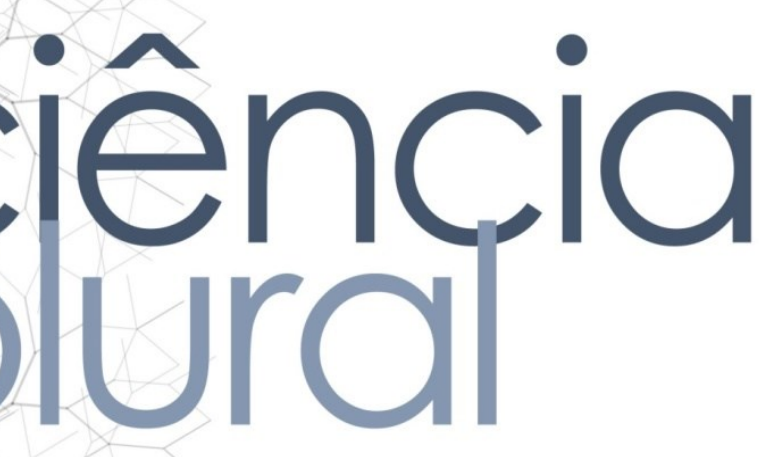

\title{
FACTORS ASSOCIATED WITH MORTALITY IN HEPATITIS C PATIENTS
}

\section{Fatores associados com mortalidade em pacientes com Hepatite $\mathbf{C}$}

Gilmar Amorim de Sousa - Professor, Department of Integrated Medicine and Gastroenterology (DMI), Federal University Rio Grande do Norte (UFRN). E-mail: gilamorimdesousa@gmail.com

Ranna Santos Pessoa • Medicine undergraduate student, Federal University Rio Grande do Norte (UFRN). E-mail: rannaspessoa@gmail.com

Marlon César Melo de Souza Filho • Medicine undergraduate student, Federal University Rio Grande do Norte (UFRN). E-mail: marlonsouzafilho@gmail.com

Daniel Fernandes Mello de Oliveira • Medicine undergraduate student, Federal University Rio Grande do Norte (UFRN). E-mail: danielfernandesmo@gmail.com

Luana Lopes Medeiros - Medicine undergraduate student, Federal University Rio Grande do Norte (UFRN). E-mail: luanalopesmedeiros@gmail.com

Dyego Leandro Bezerra de Souza - Professor, Graduate Program in Collective Health, UFRN. E-mail: dysouz@yahoo.com.br

Iris do Céu Clara Costa - Professor, Graduate Program in Collective Health, UFRN. E-mail: irisdoceu.ufrn@gmail.com

Autor responsável pela correspondência:

Gilmar Amorim de Sousa. Av. Salgado Filho 1787, Lagoa Nova, Natal, RN, Brazil, 59056-000. Fone +55 84 33422338. E-mail: gilamorimdesousa@gmail.com

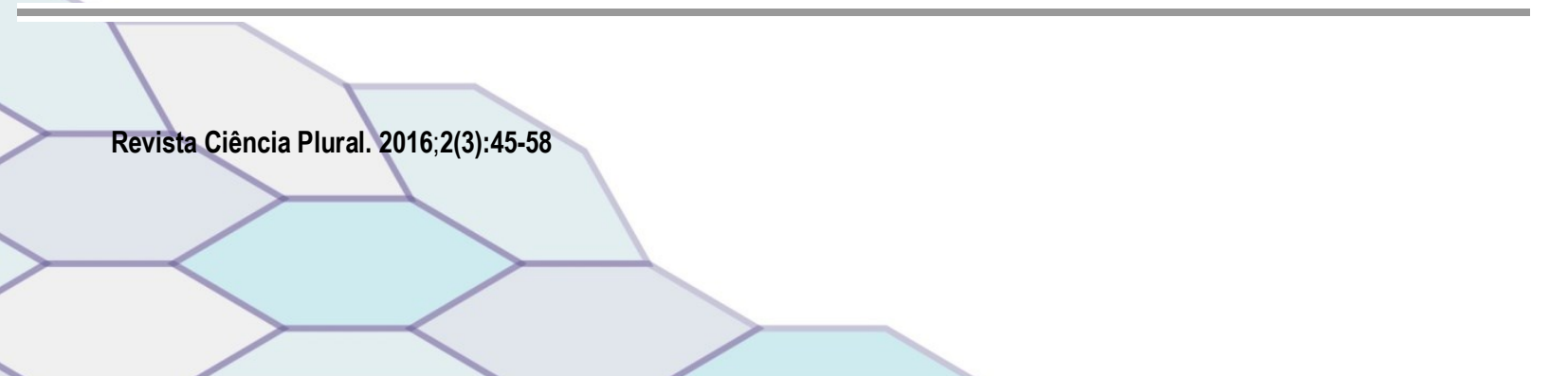




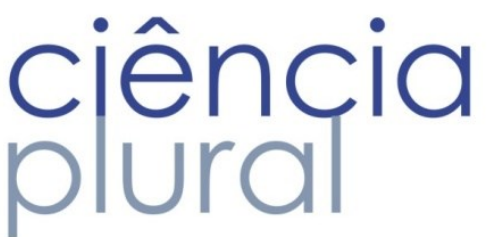

ABSTRACT

Introduction: Hepatitis $\mathrm{C}$ still is the major responsible for progressive liver disease, which evolves to its chronic form in $80 \%$ of acutely infected patients, and can cause cirrhosis, digestive hemorrhage, liver failure, liver cancer, and death. Objective: Determine the factors associated with death in hepatitis C patients. Methods: A detailed review was carried out in 10.304 medical records from the Liver Study Nucleus of the Onofre Lopes University Hospital, at the Federal University of Rio Grande do Norte (Northeast Brazil), between May 1995 and December 2013. Cases considered as suspect when the anti-HCV tested positive and confirmed when the qualitative RNA HCV tested positive (512 cases). Death was the dependent variable. The independent variables considered were: socio-demographic variables, variables associated with HCV infection, and those related to the progression of the disease. The association between independent variables and death was assessed, and the statistical significance $(\mathrm{p})$ was calculated, along with OddsRatio (OR), and confidence intervals (95\%). Results: The following associations were established with hepatitis $C$ mortality: patients over the age of 35 , treatment dropouts, diabetes mellitus, use of insulin, total bilirubin over $1.3 \mathrm{mg} / \mathrm{dL}$, International Normalized Ratio at final consultation and low albumin at initial consultation $(<3.5 \mathrm{~g} / \mathrm{dL})$, aspartate aminotransferase (AST), alanine aminotransferase (ALT), long prothrombin reaction time (PT), cirrhosis and liver carcinoma. Conclusion: The factor that most influences hepatitis $C$ is the early diagnosis of the disease, before it progresses to cirrhosis and liver carcinoma. These patients must have easy access to health services, which should be guaranteed by public policies that are specifically defined for this purpose.

Keywords: Hepatitis C; Chronic hepatitis C; Liver cirrhosis; Public policies.

\section{RESUMO}

Introdução: $\mathrm{A}$ hepatite $\mathrm{C}$ continua sendo a maior causa de doença hepática progressiva que evolui para forma crônica em $80 \%$ dos pacientes agudamente infectados, podendo desencadear cirrose, hemorragia digestiva, falência hepática, câncer de fígado e morte. Objetivos: Conhecer fatores associados ao óbito em pacientes com hepatite C. Métodos: Revisou-se 10.304 prontuários, do Núcleo de Estudos do Fígado do Hospital Universitário Onofre Lopes da Universidade Federal do Rio Grande do Norte, Brasil, entre maio-1995 e maio2013. Considerou-se casos suspeitos pacientes com anti-HCV positivo e casos confirmados, aqueles com HCV RNA qualitativo positivo, que resultou em 512 casos. 0 óbito foi a variável dependente. Foram consideradas variáveis independentes: as sócio-demográficas, as associadas à infecção pelo $\mathrm{HCV}$ e as relacionadas à progressão da doença. Avaliou-se associação das variáveis independentes e o óbito, e calculou-se significância estatística (p), Odds Ratio (OR) e intervalos de confiança de 95\% (IC 95\%). Resultados: Encontrou-se as seguintes associações com mortalidade por hepatite $\mathrm{C}$ : pacientes com idade acima de 35 anos, com abandono do tratamento, diabete melito, uso de insulina, bilirrubina total acima de 1,3 mg/dL, INR na consulta final e albumina baixa $(<3,5 \mathrm{~g} / \mathrm{dL})$ na consulta inicial, AST, ALT, TAP alargado, cirrose e hepatocarcinoma. Conclusão: Conclui-se que em função de sua magnitude e severidade, o fator de maior impacto na hepatite $C$ é a descoberta precoce da doença, antes de evoluir para cirrose e carcinoma hepático, o que presume que esses pacientes precisam ter acesso facilitado ao serviço de saúde, que deverá ser garantido por políticas públicas específicas definidas.

Palavras Chave: Hepatite C; Hepatite C crônica; Cirrose Hepática, Políticas públicas. 


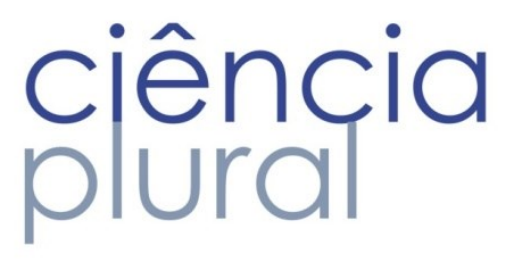

\section{Introduction}

Hepatitis $C$ is the major cause for progressive liver disease, and afflicts approximately 158 million individuals globally ${ }^{1,2}$. It is estimated that between 2007 and 2009, the costs of treating chronic hepatitis C patients in Brazil have been over 90 million dollars, with antiviral drugs being responsible for $88 \%$ of total costs $^{3}$.

Transmission occurs mainly by contact with contaminated blood and hemoderivatives, with the use of intravenous drugs being the most common risk factor. Many patients acquire the Hepatitis C Virus (HCV) with no exposition to blood. Sexual transmission, considered an improbable route, can be related to sexual practices with mucous trauma and with individuals infected with HIV4. Therefore, the most elevated rates of hepatitis $C$ are among individuals that use injectable drugs (45\% of new cases), patients with liver failure undergoing hemodialisis (prevalence varies between 6 and 38\%), and hemophiliacs (antiHCV rates of $44 \%)^{5}$.

There still are no safe predictions on the evolution of a specific patient infected with $\mathrm{HCV}$, once the differences in the evolution course of each patient depend not only on viral factors, but also depend on aspects related to the host and environment ${ }^{6}$. However, it is known that hepatitis $\mathrm{C}$ evolves to the chronic form in $80 \%$ of acutely infected patients ${ }^{7}$, leading to cirrhosis, digestive hemorrhage, liver failure, liver cancer and death - representing the major cause of liver transplants along with alcoholism ${ }^{8}$.

The factors associated with hepatitis $C$ mortality are very important for the understanding of the natural history of this infection, as well as for the prediction of which patients will present more unfavorable prognosis and which will reach more severe stages of the disease. Therefore, the current study has the objective of establishing knowledge on the factors associated with death in hepatitis $C$ patients, to guide the monitoring of the patient by the assisting physician.

\section{Materials and methods}

Study design: A sectional study was carried out, through the review of 10,304 medical records, which represent all patients from the Liver Study Nucleus (LSN), a reference service in the assistance of liver disease patients. LSN operates from the Onofre Lopes University Hospital (OLUH) at the Federal University of Rio Grande do Norte (UFRN), located in the municipality of Natal (Northeast Brazil). The analysis covered the period between May 1995 and December 2013. 


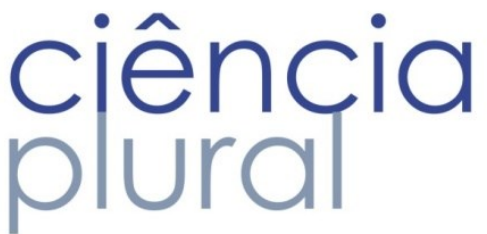

Selection of Patients: Patients that tested anti-HCV positive were considered suspect cases. Patients that tested positive for the qualitative RNA HCV test were considered confirmed cases. In the study, 512 confirmed cases of hepatitis $\mathrm{C}$ were included.

Collection of variables: Death was the dependent variable. The independent variables were: sociodemographics (age, gender, marital status, profession, color and place of birth), those associated with HCV infection (promiscuity, intimate contact with hepatitis $C$ individuals, past blood transfusions, use of intravenous drugs, health professional occupation, being a professional athlete, hemophilia, and hemodialisis treatment), and those associated with the progression of the disease ( result of the anti-HCV test, genotype, viral load, presence of cirrhosis, presence of nodules or lesions suggesting hepatocellular carcinoma (HCC) in ultrasound exam, whether a biopsy was accomplished and its result, previous antiviral treatment with the classical scheme of ribavirin and pegylated interferon, if the individual responded to treatment, if there was relapse, if the individual responded to the relapse treatment, the highest value of Alpha-Fetoprotein Blood Test, treatment dropout, if medical monitoring was abandoned, ethanolism, diabetes mellitus, use of insulin, use of hypoglycemiants, and values of: aspartate aminotransferase (AST), alanine aminotransferase (ALT), gamma-glutamyl transferase (GGT), bilirubins, prothrombin reaction time (PT), International Normalized Ratio (INR), albumin, ferritin, transferrin saturation, and platelets. Co-infections were also analyzed: hepatitis $B$ virus and HIV - HBsAg, AntiHBc-lgG, AntiHBs, AntiHIV.

Ethical aspects: All variables were collected through the review of medical records. All tests were requested according to the service routine, so that the current study did not affect medical conducts. The study was approved by the Research Ethics Committee of University Hospital Onofre Lopes (approval number 448243/2013). As this study utilized secondary data based on review of registries, there was no need for requesting informed consent forms from patients. However, the authors have committed to maintain absolute secrecy about the information obtained from the medical records.

Statistical analysis: Tabulation and data analysis utilized SPSS 17.0. For the assessment of independent variables and death, the statistical significance $(p)$ was calculated, along with OddsRatio (OR), and confidence intervals of $95 \%$ (Cl95\%). 


\section{Results and Discussion}

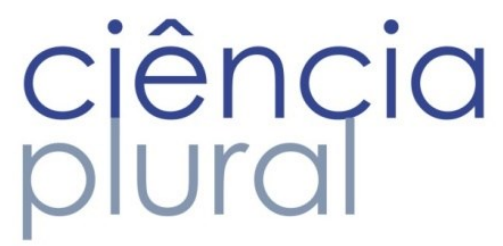

TABLE 1: Socio-demographic variables consid ered for hepatitis C patients assisted by the LSN-ONUH-UFRN betw een May 1995 and December 2013.

Natal-RN, Brazil, 2014

\begin{tabular}{|c|c|c|c|c|c|c|c|}
\hline \multirow{2}{*}{ Gender } & \multirow[t]{2}{*}{ Variable } & \multicolumn{2}{|c|}{ Deaths } & \multicolumn{2}{|c|}{ No deaths } & \multicolumn{2}{|c|}{ Bivariate analysis } \\
\hline & & $\mathbf{n}$ & $\%$ & $\mathbf{n}$ & $\%$ & OR (CI) & $p$ \\
\hline & Male & 18 & 4.85 & 353 & 95.15 & $1.85(0.53-6.40)$ & \\
\hline & Female & 3 & 2.67 & 109 & 97.33 & 1.0 & 0.330 \\
\hline \multicolumn{8}{|l|}{ Age } \\
\hline & $15-35$ years & 1 & 0.71 & 139 & 99.29 & $0.11(0.01-0.87)$ & \multirow{2}{*}{0.037} \\
\hline & $>35$ years & 20 & 5.83 & 323 & 94.17 & 1.0 & \\
\hline \multicolumn{8}{|c|}{ Marital study } \\
\hline & Not married & 9 & 4.59 & 187 & 95.41 & $1.08(0.44-2.62)$ & \multirow{2}{*}{0.86} \\
\hline & Married & 12 & 4.25 & 270 & 95.75 & 1.0 & \\
\hline \multicolumn{8}{|c|}{ Profession } \\
\hline & Related to risk & 2 & 4.08 & 47 & 95.92 & $0.91(0.20-4.05)$ & \multirow{2}{*}{0.908} \\
\hline & Unrelated to risk & 19 & 4.43 & 409 & 95.57 & 1.0 & \\
\hline \multicolumn{8}{|l|}{ Color } \\
\hline & White & 6 & 8.10 & 68 & 91.90 & $2.34(0.86-6.37)$ & \multirow{2}{*}{0.09} \\
\hline & Not white & 13 & 3.63 & 345 & 96.37 & 1.0 & \\
\hline \multicolumn{8}{|c|}{ Place of birth } \\
\hline & Natal & 15 & 5.22 & 272 & 94.78 & $1.73(0.66-4.55)$ & \multirow{3}{*}{0.262} \\
\hline & Other locations & 6 & 3.07 & 189 & 96.93 & 1.0 & \\
\hline \multicolumn{7}{|c|}{ Health professional } & \\
\hline & Yes & 2 & 9.52 & 19 & 90.48 & $2.45(0.53-11.30)$ & \multirow{2}{*}{0.249} \\
\hline & No & 19 & 4.11 & 443 & 95.89 & 1.0 & \\
\hline \multicolumn{8}{|c|}{ Promiscuity } \\
\hline & Yes & 2 & 3.57 & 54 & 96.43 & $0.75(0.17-3.32)$ & \multirow{2}{*}{0.710} \\
\hline & No & 19 & 4.67 & 387 & 95.33 & 1.0 & \\
\hline \multicolumn{8}{|c|}{ Professional athlete } \\
\hline & Yes & 1 & 3.84 & 25 & 96.16 & $0.85(0.11-6.62)$ & \multirow{2}{*}{0.880} \\
\hline & No & 20 & 4.47 & 427 & 95.53 & 1.0 & \\
\hline \multicolumn{8}{|c|}{ Aband onment of treatment } \\
\hline & Yes & 1 & 0.31 & 318 & 99.69 & $0.02(0.00-0.16)$ & \multirow{2}{*}{$\begin{array}{c}<0.000 \\
5\end{array}$} \\
\hline & No & 20 & 12.65 & 138 & 87.35 & 1.0 & \\
\hline \multicolumn{8}{|c|}{ Past transfusions } \\
\hline & Yes & 8 & 8 & 92 & 92 & $2.37(0.95-5.90)$ & \multirow{2}{*}{0.063} \\
\hline & No & 13 & 3.53 & 355 & 96.47 & 1.0 & \\
\hline \multicolumn{8}{|c|}{ Contact $w$ ith HCV carriers } \\
\hline & Yes & 4 & 6.55 & 57 & 93.45 & $1.61(0.52-4.98)$ & \multirow{2}{*}{0.401} \\
\hline & No & 17 & 4.15 & 392 & 95.85 & 1.0 & \\
\hline
\end{tabular}

A total of 10.304 medical records were reviewed, of which all suspect cases were selected for analysis (positive anti-HCV test), which corresponded to 1592 cases (15.45\%). Of these, 1.080 were excluded because of non-confirmation. Therefore 512 patients constituted the final sample of the study, corresponding to $4.96 \%$ of assisted cases. Of the confirmed hepatitis $C$ cases, 21 medical records (4.10\%) registered deaths.

Considering the socio-demographic variables, the age group over 35 years of age presented positive association with mortality when compared with patients between 15 and 35 years of age. None of the blood donors included in the study (248 patients) deceased. Of the non-donors (213 patients), 21 patients deceased. 


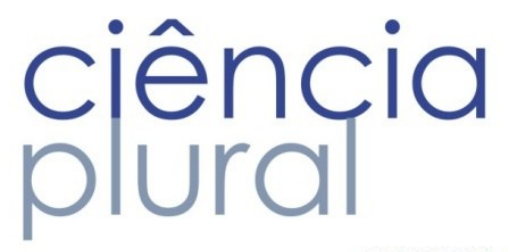

TABLE 2: Comorbidities of the hepatitis C patients that deceased, assisted by the LSN-

OLUH-UFRN, in the period May 1995 - December 2013. Natal-RN, Brazil, 2014.

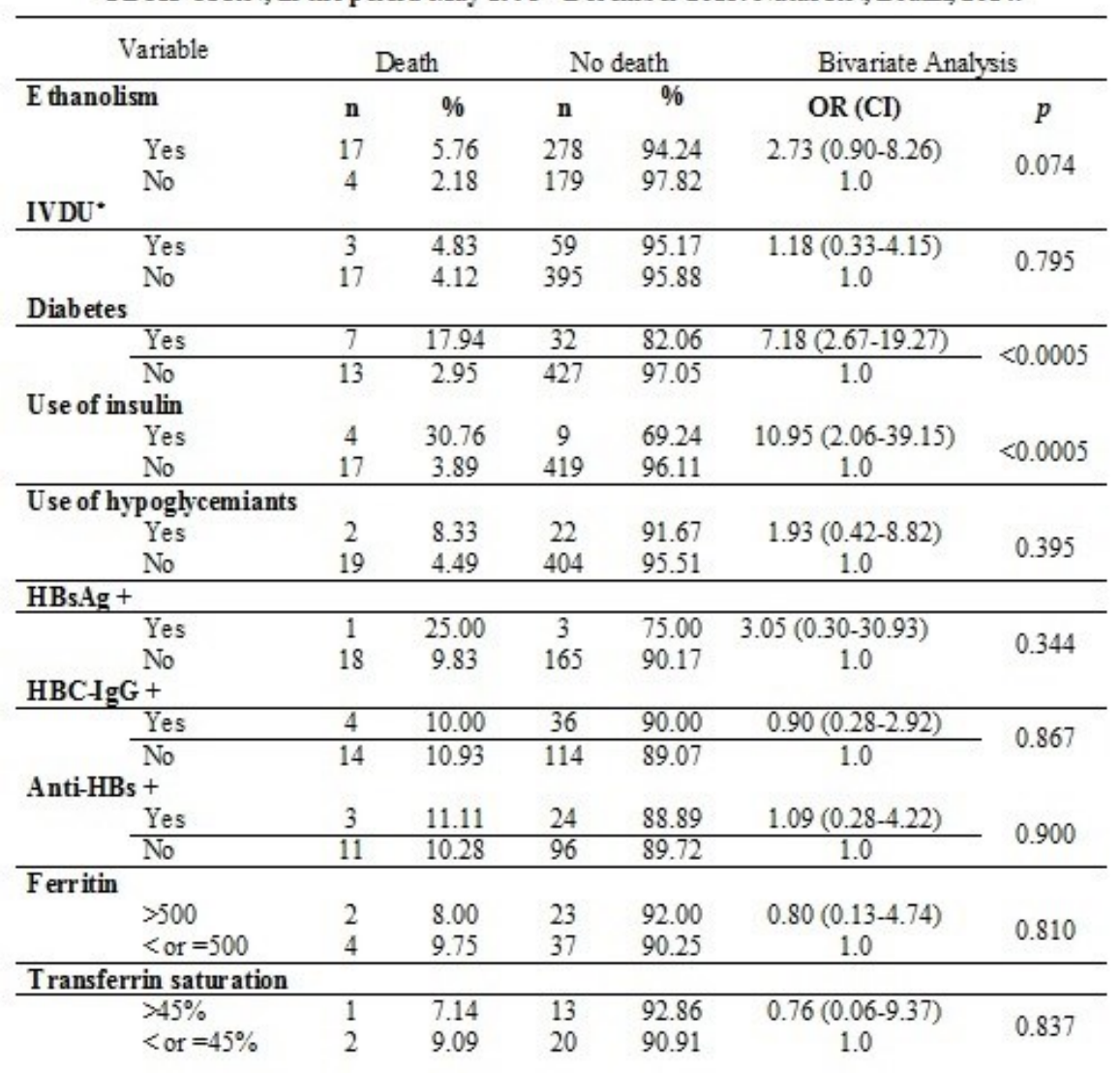

Regarding comorbidities, mortality was associated with diabetes as well as with the use of insulin. Of the 18 obese included in the study, none of these cases led to death; of the patients that presented normal Body Mass Index (BMI) (444 patients), 21 deceased. Only one HIV-positive patient was included and did not decease; of the 71 HIV-negative patients, five deceased. Three hemophiliac patients were included in the study, of which none deceased; nevertheless, of the 580 non-hemophiliacs, 21 deceased. Sixteen patients were undergoing hemodialisis treatment, and none deceased.

Positive association with mortality was verified for the following clinical and laboratory aspects: AST above $60 \mathrm{UI} / \mathrm{mL}$ at initial consultation, ALT above $60 \mathrm{UI} / \mathrm{mL}$ at initial consultation, total bilirubin of at least $1.3 \mathrm{mg} / \mathrm{dL}$, and PT lower than $70 \%$ at initial and final consultations. INR above 1.3 at final consultation corresponded to a $36.84 \%$ mortality; when INR was 1.3 or lower, mortality was $7.14 \%$. Albumin was also positively related to mortality, when lower than $3.5 \mathrm{~g} / \mathrm{dL}$. Of the patients that presented albumin levels equal or above $3.5 \mathrm{~g} / \mathrm{dL}$ (39 patients), none deceased; however of the 46 patients with albumin under $3.5 \mathrm{~g} / \mathrm{dL}, 17$ deceased. Of the four patients with Metavir A equal to 3 (severe liver inflammation), none deceased; and of the 75 patients with Metavir A under 3, two deceased. Of the patients that responded to treatment (43), none deceased, but of the 24 patients that did not respond to treatment, nine deceased. 


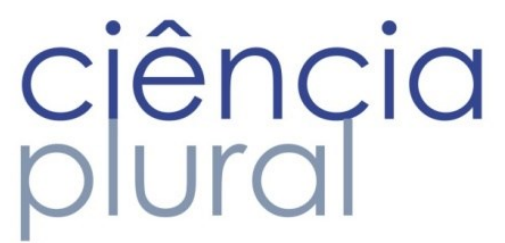

There was association with abandonment of treatment, ultrasound findings compatible with cirrhosis, and radiology diagnosis of HCC through CT scan.

The mortality association established with patients over 35 years of age, when compared with the age group between 15 and 35 years of age, is probably related to the discovery of the disease in more advanced stages, to a greater number of associated comorbidities, and to a lower functional reserve. Advanced age is already described in literature as a factor related to increased mortality. In a cohort study carried out between 2007 and 2009 in Los Angeles (U.S.A.), the age group between 45 and 64 years of age was considered as a risk factor $(\mathrm{OR}=1.83 ; \mathrm{Cl}=1.54-2.18 ; \mathrm{p}<0.001)$, as well as the age group over 65 years of age $(\mathrm{OR}=2.77 ; \mathrm{Cl}=2.3$ 3.34), when compared with the age group under 45 years of age, which is the reference age group ${ }^{9}$. Nevertheless, it is perceptible that, over 35 years of age - as established herein - there is already increased association with mortality when compared to lower age groups (and not only after the 5th or 6th decades of life).

In the present study, diabetes mellitus was associated with hepatitis $\mathrm{C}$ mortality; this disease has been reported in literature as being four times more frequent in the population with liver disease than in the general population ${ }^{10}$. The diabetic population in the analyzed group corresponded to $8.14 \%$ of patients, which is a much lower incidence than found in literature $(17,2 \%)^{11,12}$. Studies have shown that diabetics present more fibrosis (Metavir F3 and F4) than non-diabetics ${ }^{12}$ however, other associated factors must be taken into account, such as the fact that the majority of diabetics present advanced age, elevated BMI and more liver steatosis $^{13}$. There are also descriptions of higher incidences of cirrhosis, HCC, and higher mortality ${ }^{13}$.

The incidence of diabetes is higher in hepatitis $C$ patients than in the general population, and diabetics have probably more chances to acquire HCV due to the use of needles for insulin and capillary glycemia. Also, diabetics develop cirrhosis more frequently, which is a known risk factor for hepatitis C. Another important factor is that the interferon-based treatment can cause diabetes. There are reports that HCV patients with diabetes present higher risk for the development of HCC, discompensation of base liver disease, and present lower survival rates ${ }^{14}$. However, a report was found showing that the association between diabetes and mortality in HCC patients was non-significant ${ }^{14}$.

Another association established herein was the use of insulin as a factor associated with increased mortality. No description was found in scientific literature on such association. Since diabetes is a factor widely associated with increased mortality, it was expected that its adequate treatment decreased mortality, as shown by some studies in which patients were treated with metformin and presented lower incidence of HCC, lower 


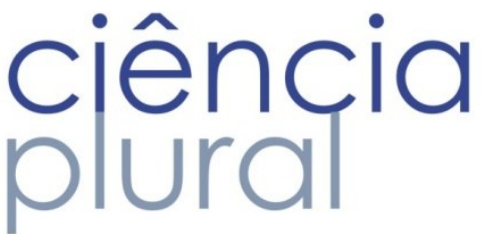

mortality rates and lower necessity of transplants. Another study demonstrated that the survival of patients after HCC resection does not change if the patients are diabetic, but is higher in patients that control glucose (maintaining glycosylated hemoglobin under $6.5 \%)^{14}$. This corroborates the fact that adequate treatment of diabetes must reduce mortality.

Another hypothesis for the higher association between the use of insulin and mortality verified herein is that patients that require the use of insulin present more advanced diabetes, which is no longer controlled by oral hypoglycemiants only, and probably these patients present liver steatosis, microvascular diseases, and other alterations that can lead to early death.

Regarding the AST levels at initial consultation, the present study stratified patients in those with levels over $60 \mathrm{UI} / \mathrm{mL}$ and those with levels equal or under $60 \mathrm{UI} / \mathrm{mL}$, with an association established between high levels and mortality. In this way, it can be thought that these liver enzymes are useful to assess the individual risk of death in hepatitis $\mathrm{C}$ patients since the first consultation.

A study carried out in Michigan (U.S.A.) investigated the relationship between the level of fibrosis and the APRI score (AST to Platelet Ratio Index), concluding that there was high positive correlation between these two variables and therefore, there was high accuracy in the prediction of more advanced stages of hepatitis $\mathrm{C}$ when severe fibrosis and cirrhosis were also present ${ }^{15}$. Therefore, higher levels of AST or lower levels of platelets lead to higher APRI scores and consequently, more correlation with advanced stages of the disease ${ }^{15}$.

An observational study with 133 patients described correlations of AST and ALT with the incidence of HCC. Despite presenting generally lower levels than ALT, AST is usually elevated in most cases, and can be better utilized as screening method for more advanced stages ${ }^{16}$.

Total bilirubin above $1.3 \mathrm{mg} / \mathrm{dL}$ presented association with mortality herein. This occurred because, due to the natural history of the disease itself, there is a trend towards the progressive increase of this marker (involvement of liver). Therefore, the bilirubin values can be used as an indicator of advanced disease. Existing studies show this relationship between high levels of bilirubin and mortality, such as a multicentric study conducted in the United Kingdom, in which the laboratory measurements that presented relationship with increased mortality were: high levels of bilirubin, high levels of immunoglobulin $\lg \mathrm{M}$ or $\operatorname{lgA}$, or low levels of albumin ${ }^{16}$. 


\section{ciência plura}

TABLE 3: Clinical aspects and evolution of patients that deceased from hepatitis C, assisted by the LSN-OLUH-UFRN, in the period May 1995 - December 2013. Natal-RN, Brazil, 2014.

\begin{tabular}{|c|c|c|c|c|c|c|c|}
\hline \multicolumn{2}{|c|}{ Variable } & \multicolumn{2}{|c|}{ Death } & \multicolumn{2}{|c|}{ No death } & \multicolumn{2}{|c|}{ Bivariate analysis } \\
\hline & & $\mathbf{n}$ & $\%$ & $\mathbf{n}$ & $\%$ & OR (CI) & $p$ \\
\hline \multirow[t]{2}{*}{ AST IC } & $>60 \mathrm{UI} / \mathrm{mL}$ & 16 & 12.80 & 109 & 87.20 & $6.94(1.97-24.44)$ & \multirow{2}{*}{0,003} \\
\hline & $<\mathrm{or}=60 \mathrm{UI} / \mathrm{mL}$ & 3 & 2.06 & 142 & 97.94 & 1.0 & \\
\hline \multicolumn{8}{|l|}{ ALT IC } \\
\hline & $>60 \mathrm{UL} / \mathrm{mL}$ & 15 & 10.27 & 131 & 89.73 & $3.57(1.15-11.07)$ & \\
\hline & $<\mathrm{or}=60 \mathrm{UI} / \mathrm{mL}$ & 4 & 3.10 & 125 & 96.90 & 1.0 & 0,027 \\
\hline Gama-G & & & & & & & \\
\hline & $>60 \mathrm{UL} / \mathrm{mL}$ & 14 & 9.52 & 133 & 90.48 & $2.21(0.77-6.33)$ & \\
\hline & $<\mathrm{or}=60 \mathrm{UL} / \mathrm{mL}$ & 5 & 4.54 & 105 & 95.46 & 1.0 & 0,140 \\
\hline Gama-G & & & & & & & \\
\hline & $>60 \mathrm{UI} / \mathrm{mL}$ & 9 & 9.27 & 88 & 90.73 & $1.15(042-3.11)$ & \\
\hline & $<\mathrm{or}=60 \mathrm{UL} / \mathrm{mL}$ & 8 & 8.16 & 90 & 91.84 & 1.0 & 0,783 \\
\hline Total bi & IC & & & & & & \\
\hline & >or $=1.3$ & 9 & 20.00 & 36 & 80.00 & $2.71(0.93-7.86)$ & \\
\hline & $<1.3$ & 7 & 8.43 & 76 & 91.57 & 1.0 & 0,066 \\
\hline Total bil & FC & & & & & & \\
\hline & >or $=1.3$ & 11 & 23.40 & 36 & 76.60 & $3.81(1.12-12.96)$ & \\
\hline & $<1.3$ & 4 & 7.40 & 50 & 92.60 & 1.0 & 0,032 \\
\hline PT IC & & & & & & & \\
\hline & $<70$ & 11 & 15.27 & 61 & 84.73 & $3.90(1.38-11.05)$ & \\
\hline & >or $=70$ & 6 & 4.41 & 130 & 95.59 & 1.0 & 0,010 \\
\hline PT FC & & & & & & & \\
\hline & $<70$ & 12 & 20.00 & 48 & 80.00 & $6.18(1.89-20.19)$ & \\
\hline & >or $=70$ & 4 & 3.88 & 99 & 96.12 & 1.0 & 0,003 \\
\hline INR IC & & & & & & & \\
\hline & $>1.3$ & 6 & 37.50 & 10 & 62.50 & $4.05(0.94-17.41)$ & \\
\hline & $<\mathrm{or}=1.3$ & 4 & 12.90 & 27 & 87.10 & 1.0 & 0,060 \\
\hline INR FC & & & & & & & \\
\hline & $>1.3$ & 7 & 36.84 & 12 & 63.16 & $7.58(1.36-42.09)$ & \\
\hline & $<\mathrm{or}=1.3$ & 2 & 7.14 & 26 & 92.86 & 1.0 & 0,021 \\
\hline Albumir & & & & & & & \\
\hline & $<3.5$ & 12 & 27.90 & 31 & 72.1 & $6.87(2.05-22.98)$ & \\
\hline & >or $=3.5$ & 4 & 5.33 & 71 & 94.67 & 1.0 & 0,002 \\
\hline Alpha-F & ein & & & & & & \\
\hline & $=0 r>20 \mathrm{mcg} / \mathrm{L}$ & 6 & 22.22 & 21 & 77.78 & $1.57(0.44-5.52)$ & \\
\hline & $<20 \mathrm{mcg} / \mathrm{L}$ & 6 & 15.38 & 33 & 84.62 & 1.0 & 0,481 \\
\hline Platelets & & & & & & & \\
\hline & $<150.000$ & 10 & 10.52 & 85 & 89.48 & $2.02(0.77-5.34)$ & \\
\hline & >or $=150.000$ & 8 & 5.47 & 138 & 94.53 & 1.0 & 0,152 \\
\hline Platelets & & & & & & & \\
\hline & $<150.000$ & 12 & 12.00 & 88 & 88.00 & $2.64(0.89-7.80)$ & \\
\hline & >or $=150.000$ & 5 & 4.90 & 97 & 95.10 & 1.0 & 0,078 \\
\hline Biopsy & & & & & & & \\
\hline & & 3 & 3.15 & 92 & 96.85 & $0.69(0.19-2.42)$ & \\
\hline & & 17 & 4.48 & 362 & 95.52 & 1.0 & 0.567 \\
\hline Metavir & & & & & & & \\
\hline & & 2 & 14.28 & 12 & 85.72 & $10.0(0.83-119.32)$ & \\
\hline & & 1 & 1.63 & 60 & 98.37 & 1.0 & 0.069 \\
\hline Genotyp & & & & & & & \\
\hline & pe 1 & 7 & 4.96 & 134 & 95.04 & $0.31(0.09-1.05)$ & \\
\hline & pe not 1 & 5 & 14.28 & 30 & 85.72 & 1.0 & 0.061 \\
\hline Viral loa & & & & & & & \\
\hline & $00 \mathrm{UL} / \mathrm{mL}$ & 7 & 7.14 & 91 & 92.86 & $0.75(0.33-2.50)$ & \\
\hline & $0.000 \mathrm{UL} / \mathrm{mL}$ & 5 & 9.25 & 49 & 90.75 & 1.0 & 0.644 \\
\hline Underw & atment & & & & & & \\
\hline & & 6 & 6.31 & 89 & 93.69 & $2.77(0.96-8.01)$ & \\
\hline & & 9 & 2.36 & 371 & 97.64 & 1.0 & 0.058 \\
\hline Relapse & & & & & & & \\
\hline & & 1 & 4.54 & 21 & 95.46 & $0.47(0.04-4.89)$ & \\
\hline & & 3 & 9.09 & 30 & 90.91 & 1.0 & 0.533 \\
\hline Suspens & reatment & & & & & & \\
\hline & & 7 & 18.42 & 31 & 81.58 & $5.19(1.01-26.67)$ & \\
\hline & & 2 & 4.16 & 46 & 95.84 & 1.0 & 0.048 \\
\hline Ultrasou & rhosis & & & & & & \\
\hline & & 18 & 32.14 & 38 & 67.86 & $35.52(7.89-159.79)$ & \\
\hline & & 2 & 1.31 & 150 & 98.69 & 1.0 & $<0.0005$ \\
\hline Ultrasou & dules & & & & & & \\
\hline & & 7 & 23.33 & 23 & 76.67 & $3.74(1.35-10.36)$ & \\
\hline & & 13 & 7.51 & 160 & 92.49 & 1.0 & 0.011 \\
\hline Ultrasou & $\mathrm{CC}$ & & & & & & \\
\hline & & 3 & 37.50 & 5 & 62.50 & $5.90(1.30-26.74)$ & \\
\hline & & 18 & 9.23 & 177 & 90.77 & 1.0 & 0.021 \\
\hline CT scan & & & & & & & \\
\hline & & 4 & 50.00 & 4 & 50.00 & $11.80(2.24-62.03)$ & \\
\hline & & 5 & 7.81 & 59 & 92.19 & $\frac{11.00(2.2+7.02 .00)}{1.0}$ & 0.004 \\
\hline
\end{tabular}




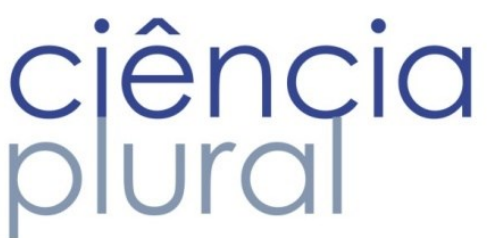

The prothrombin index (PI) is a serological marker that can be related to the pathological degree of liver fibrosis ${ }^{24}$, and is used to detect fibrosis even in early stages. As occurred with PI, PT was found to be an independent predictive factor for stage F2-F4 in research carried out with chronic un-treated hepatitis $\mathrm{C}$ patients ${ }^{17}$. In the present study, the PT of initial and final consultations were analyzed (PT IC and PT FC, respectively), and both presented strong association with mortality, indicating that this marker can be used at the moment of diagnosis to predict the risk of death of the patient, as well as during follow-ups, indicating those patients that are at higher risks of unfavorable outcomes.

INR over 1.3 at final consultation was a factor associated with mortality in the studied population. At the final consultation, the majority of chronic hepatitis $\mathrm{C}$ patients had already developed cirrhosis, and it is frequent that INR increases along with the worsening of cirrhosis. INR at initial consultation did not present significant association with mortality, which leads to the affirmation that INR cannot be utilized as a prognosis factor for mortality, but rather could be used to mark the severity of the infection. However, some studies include this laboratory data in prognosis scores. INR has been utilized to standardize PT in liver diseases, and is included in some prognosis models for HCC and cirrhosis such as the Child-Turcotte-Pugh and MELD (model for end stage liver disease) ${ }^{18}$. Therefore the association between increased INR and mortality suggests association of severe liver disease (HCC or cirrhosis).

Low albumin $(<3.5 \mathrm{~g} / \mathrm{dL})$ levels at initial consultation were associated with higher mortality herein. The scientific literature affirms that albumin is generally normal until the development of fibrosis ${ }^{19}$, cirrhosis or initial $\mathrm{HCC}^{27}$. No studies were found presenting association between low albumin and increased mortality, but this relationship can be due to the advanced staging of the disease at the time that patients arrive at the reference service. These patients already arrive with pronounced markers of cirrhosis or initial cancer, and this can lead to death more frequently than in cases where patients present albumin levels of at least $3.5 \mathrm{~g} / \mathrm{dL}$ at initial consultation.

No association was established between high GGT and thrombocytopenia with mortality, despite the fact that literature indicates the existence of such a relationship ${ }^{20}$. No statistically-significant association was verified between mortality and co-infection by hepatitis B, HIV, alcoholism, and obesity; however, research have demonstrated that these factors increase the risk of $\mathrm{HCC}$, a negative prognosis factor for the survival of hepatitis $\mathrm{C}$ patients ${ }^{18}$.

The importance of the treatment of hepatitis $C$ to avoid bad outcomes (death) has been clearly determined, as $55-85 \%$ of the individuals that acquire hepatitis $\mathrm{C}$ will remain infected by HCV after the acute 
phase ${ }^{17}$, with a 5-25\% risk of developing cirrhosis in 25-30 years. Also, individuals with cirrhosis are at risk of developing liver discompensation (30\% in 10 years) and HCC (1-3\% per year $)^{21}$, which are related to causes of death in the natural history of the disease. Data obtained herein were corroborated by scientific literature in the following aspect: treatment abandonment lead to death. As aforementioned, treatment is important to avoid the evolution towards more advanced forms, reducing therefore the mortality rates.

In this study, ultrasound exams that revealed cirrhosis and nodules, and CT scans diagnosing HCC presented positive association with increased mortality. It can be deduced that after the development of cirrhosis, mortality increases significantly, i.e., the ideal moment to intervene would be before the onset of cirrhosis and HCC. This association between cirrhosis and mortality is well-established in the scientific literature, which has recently demonstrated that stage 4 of liver fibrosis increases mortality and events related to the liver 22.23 .

HCC screening through ultrasound in patients with cirrhosis compensated with the HCV virus can increase survival in up to 31 months and reduce 5 -year mortality in $20 \%(p<0.0001)$. According to the literature, ultrasound follow-ups should be semi-annual, as survival in these cases is increased by 15 months in comparison with those patients that realize annual follow-ups only, as cancer can be detected in earlier stages ${ }^{24}$.

No association was established between mortality and the following variables: gender, marital status, profession, color, place of birth, being a health professional, promiscuity, and past transfusions and intimate contact with HCV carriers. Studies have corroborated that blood transfusions are not related with increase in mortality. Regarding gender, males present faster progression towards fibrosis and the African-American race presents slower progression ${ }^{25}$.

The main limitations of the study were the number of incomplete medical records, which led to the loss of data, and the lack of follow-ups for many patients, due to difficulties in accessing services. In the presented analysis, a cross-sectional character was selected, although a prospective design would be more adequate to analyze the factors leading to death. However, data were collected from a reference service in hepatology, which aggregates value to the study, and several of the findings associated with the evolution of HCV infection to death were corroborated by literature. 


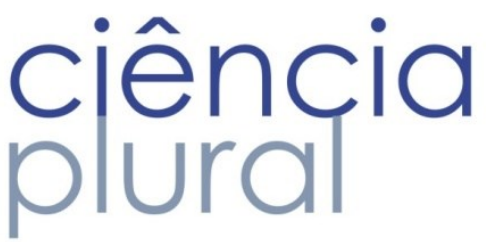

Conclusion

The present study defined clinical, epidemiological and laboratory parameters that can be potential indicators of factors leading to death and that serve as signals for the doctors, indicating that specific patients must be closely monitored. The results obtained reinforce the necessity of closely monitoring patients that present: age over 35, treatment dropout history, diabetes, use of insulin, high AST, high ALT, high total bilirubin, long PT, high INR, low albumin, history of suspended treatment, cirrhosis and HCC. It was observed that the most impacting factor was the early diagnosis of the disease, before it evolves to HCC and cirrhosis. These patients must gain easy access to health services, which can be achieved through the implementation of public policies. Besides these contributions, the findings exposed herein interfere directly in the clinical practice, allowing for the individual assistance to patients with the hepatitis $\mathrm{C}$ virus, aiming at the reduction of mortality.

\section{References}

1. World Health Organization. Guidelines for the screening, care and treatment of persons with hepatitis $C$ infection. WHO Library Cataloguing-in-Publication Data 2014; 1-123

2. Martins T, Narciso-Schiavon JL, Schiavon LL. Epidemiologia da infecção pelo vírus da hepatite C. Rev Assoc Med Bras. 2011;57(1):107-112.

3. Blatt CR, Bernardo NLMC, Rosa JA, Bagatini F, Alexandre RF, Neto GB, et al. An Estimate of the Cost of Hepatits C Treatment for the Brazilian Health System. Value Health 2012;1(2):129-135.

4. Wang $X$, Zhang A, Sun $\mathrm{H}$. Power metabolics in diagnosis and biomarker discovery of hepatocellular carcinoma. Hepatology. 2013; 57(5):2072-2077.

5. Rachel J. Wilson, Div of Viral Hepatitis, National Center for HIVIAIDS, Viral Hepatitis, STD, and TB Prevention, CDC. July 27, 2012 / 61(29);545-549

6. Vasconcelos RR, Tengan FM, Cavalheiro NP, Ibrahim K, Pereira H, Barone AA. Factors associated with severe evolution forms of chronic infection with hepatitis C virus. Rev Soc Bras Med Trop. 2006; 39(5): 433438.

7. Alberti A, Vario A, Ferrari A, Pistis R. Review article: chronic hepatits $C$ - natural history and cofactors. Aliment Pharmacol Ther. 2005; 22(Suppl. 2): 74-78.

8. Ghany MG, Strader DB, Thomas DL, Seeff LB. Diagnosis, management and treatment of hepatitis C: an update. Hepatology. 2009; 49(4): 1335-1374.

9. Sie L, Gatto NM, Bancroft E. Hospitalizations due to hepatitis C in los angeles county, 2007-2009: Case characteristics and factors associated with mortality. J Viral Hepat. 2013; 20(9): 628-37. 


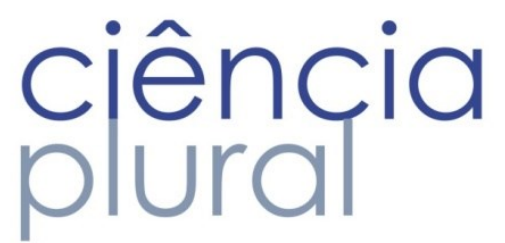

10. Di BisceglieAM, Stoddard AM, Dienstag JL, Shiffman ML, Seeff LB, Bonkovsky HL, et al. Excess mortality in patients with advanced chronic hepatitis C treated with long-term peginterferon. Hepatology. 2011; 53(4):1100-8.

11. Custro N, Caraccio A, Ganci A, Scafidi V, Campagna P, Di Prima L. Glycemic homeostasis in chronic viral hepatitis and liver cirrhosis. Diabetes Matab. 2001; 27(4 Pt 1): 476-81.

12. Kabbaj N, Errabih I, Guédira M, El Atmani H, Benabed K, Al Hamany Z, et al. Hépatitevirale C etdiabète: influence du diabètesurl'évolution de l'hépatopathie. Ann Endocrinol. 2006; 67(3): 233-237.

13. Papatheodoridis GV, Chrysanthos N, Savvas S, Sevastianos V, Kafiri G, Petraki K, et al. Diabetes mellitus in chronic hepatitis B and C: prevalence and potential association with the extent of liver fibrosis. J Viral Hepat. 2006; 13(5): 303-310.

14. Zeng QL, Feng GH, Zhang JY, Chen Y, Yang B, Huang HH, et al. Risk factors for liver-related mortality in chronic hepatitis C patients: a deceased case-living control study. World J Gastroenterol. 2014; 20(18): 55195526.

15. Wai CT, Greenson JK, Fontana RJ, Kalbfleisch JD, Marrero JA,Conjeevaram HS, et al. A simple noninvasive indexcanpredictbothsignificiant fibrosis and cirrhosis in patients with chronic hepatitis $\mathrm{C}$. Hepatology. 2003; 38(2): 518-26.)

16. Anderson FH, Zeng L, Rock NR, Yoshida EM. An assessment of the clinical utility of serum ALT and AST in chronic hepatitis C. Hepatol Res. 2000; 18(1): 63-71.

17. Lawson A, Hagan S, Rye K, Taguri N, Ratib S, Zaitoun AM, et al. The natural history of hepatitis C with severe hepatic fibrosis. J Hepatol. 2007; 47(1): 37-45.

18. Myers RP, De Torres M, Imbert-Bismut F, Ratziu V, Charlotte F, Poynard T. Biochemical markers of fibrosis in patients with chronic hepatitis C: A comparison with prothrombin time, platelet count, and ageplatelet index. Dig Dis Sci. 2003; 48(1): 146-53.

19. Saad WE, Darwish WM, Davies MG, Kumer S, Anderson C, Waldman DL, et al. Transjugular intrahepatic portosystemic shunts in liver transplant recipients: technical analysis and clinical outcome. AJR Am J Roentgenol. 2013; 200(1): 210-8.

20. El-mezayen HA, Darwish H. Development of a novel score for early detection of hepatocellular carcinoma among high-risk hepatitis C virus patients. Tumor Biol. 2014; 35(7): 6501-6509.

21. Vasconcelos RR, Tengan FM, Cavalheiro NP, Ibranhim K, Pereira H, Barone AA. Fatores associados às formas evolutivas graves da infecção crônica pelo vírus da hepatite C. Rev Soc Bras Med Trop. 2006; 39(5): 433-438.

22. Thomas DL, Seeff LB. Natural history of hepatitis C. Clin Liver Dis 2005; 9: 383-398. 


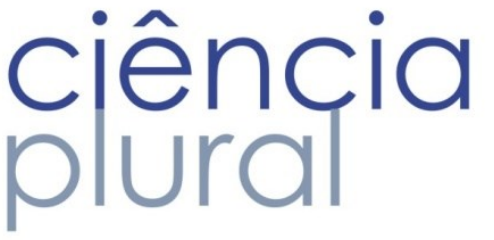

23. Dieperink E, Pocha $C$, Thuras $P$, Knott A, Colton S, Ho SB. All-cause mortality and liver-related outcomes following successful antiviral treatment for chronic hepatites C. Dig Dis Sci. 2014; 59(4): 872-880.

24. Mourad A, Burban SD, Carrié NG, Vantroys TR, Rosa I, Bouvier AM, et al. Hepatocellular Carcinoma screnning in patients with compensated hepatitis $\mathrm{C}$ virus $(\mathrm{HCV})$ - related cirrhosis aware of their HCV status improves survival: a modeling approach. Hepatology. 2014; 59(4): 1471-1481.

25. Marabita F, Aghemo A, De Nicola S, Rumi MG, Cheroni C, Scavelli R, et al. Genetic variation in the interleukin-28B gene is not associated with fibrosis progression in patients with chronic hepatitis $\mathrm{C}$ and known date of infection. Hepatology 2011; 54(4):1127-34. 